\title{
Model Pembelajaran Kolaboratif dengan Tutor Sebaya pada Pokok Bahasan Rangkaian Seri-Paralel Hambatan Listrik
}

\author{
Sumarli, Eka Murdani \\ STKIP Singkawang Kalimantan Barat \\ Surat-e: aerlie.cool@gmail.com \\ Pada pelaksanaan kegiatan belajar mengajar di kelas masih sering ditemukan peserta didik yang \\ kurang aktif atau tidak aktif sama sekali dalam mengikuti kegiatan pembelajaran. Hal tersebut \\ menyebabkan tidak meratanya ilmu yang disampaikan oleh seorang guru dan terjadi kesulitan \\ dalam melakukan penilaian kepada peserta didik di dalam kelas. Model pembelajaran kolaboratif \\ dengan tutor sebaya merupakan salah satu solusi yang bisa diterapkan dalam kegiatan pembelajaran \\ di kelas. Setiap kelompok terdiri dari peserta didik yang berprestasi rendah, sedang dan peserta \\ didik yang berprestasi tinggi bertindak sebagai tutor. Tujuannya agar setiap peserta didik merasa \\ terlibat aktif dalam proses pembelajaran dan tidak malu dalam mengemukakan pendapat atau \\ gagasan kepada sesama teman kelompoknya. Dengan demikian akan didapatkan pemerataan ilmu \\ yang diterima oleh peserta didik dalam kegiatan proses pembelajaran. Telah dibuat Rencana \\ Pelaksanaan Pembelajaran (RPP) mengenai pokok bahasan Rangkaian Seri-Paralel Hambatan \\ Listrik yang sesuai dengan model pembelajaran kolaboratif dengan tutor sebaya.
}

Kata kunci: pembelajaran kolaboratif, tutor sebaya

\section{Pendahuluan}

Pada pelaksanaan kegiatan belajar mengajar di kelas masih sering ditemukan peserta didik yang kurang aktif atau tidak aktif sama sekali dalam mengikuti kegiatan pembelajaran. Hal tersebut menyebabkan tidak meratanya ilmu yang disampaikan oleh seorang guru dan terjadi kesulitan dalam melakukan penilaian kepada peserta didik di dalam kelas.

Munculnya pembelajaran kolaboratif bermula dari perspektif filosofis terhadap konsep belajar. Untuk dapat belajar, seseorang harus memiliki pasangan. Pada tahun I9I6, Dewey menulis sebuah buku "Democracy and Education" yang isinya bahwa kelas merupakan cermin masyarakat dan berfungsi sebagai laboratorium untuk belajar tentang kehidupan nyata. Pemikiran Dewey yang utama tentang pendidikan adalah (Imron, 1996; Manurung dan Nuryani, 2010):

I. Peserta didik hendaknya aktif, learning by doing,

2. Belajar hendaknya didasari motivasi intrinsik,

3. Pengetahuan adalah berkembang, tidak bersifat tetap,
4. Kegiatan belajar hendaknya sesuai dengan kebutuhan dan minat peserta didik,

5. Pendidikan harus mencakup kegiatan belajar dengan prinsip saling memahami dan saling menghormati satu sama lain, artinya prosedur demokratis sangat penting,

6. Kegiatan belajar hendaknya berhubungan dengan dunia nyata dan bertujuan mengembangkan dunia tersebut.

Pembelajaran kolaboratif dapat menyediakan peluang untuk menuju pada kesuksesan praktek-praktek pembelajaran. Sebagai teknologi untuk pembelajaran (technology for instruction), pembelajaran kolaboratif melibatkan partisipasi aktif para peserta didik dan meminimisasi perbedaan-perbedaan antar individu. Pembelajaran kolaboratif telah menambah momentum pendidikan formal dan informal dari dua kekuatan yang bertemu, yaitu : 
I. Realisasi praktek, bahwa hidup di luar kelas memerlukan aktivitas kolaboratif dalam kehidupan di dunia nyata.

2. Menumbuhkan kesadaran berinteraksi sosial dalam upaya mewujudkan pembelajaran bermakna.

Dari uraian di atas, penulis memiliki ide untuk memperbaiki sistem pembelajaran tersebut dengan membuat model pembelajaran kolaboratif dengan tutor sebaya. Sistem pembelajarannya menggunakan prinsip kerja sama peserta didik dalam satu kelompok. Pada kelompok tersebut terdapat beberapa peserta didik yang terdiri dari peserta didik yang berprestasi rendah, berprestasi sedang dan peserta didik yang berprestasi tinggi bertindak sebagai tutor. Dengan demikian peserta didik akan merasa terlibat aktif dalam proses pembelajaran dan tidak malu dalam mengemukakan pendapat atau gagasan kepada sesama teman kelompoknya sehingga akan didapatkan pemerataan ilmu yang diterima oleh peserta didik dalam kegiatan proses pembelajaran di kelas.

\section{Landasan Teori}

Model pembelajaran mempunyai makna yang lebih luas daripada strategi, metode atau prosedur pembelajaran. Istilah model pembelajaran mempunyai 4 ciri khusus yang tidak dimiliki oleh strategi atau metode pembelajaran :

I. Rasional teoritis yang logis yang disusun oleh pendidik.

2. Tujuan pembelajaran yang akan dicapai

3. Langkah-langkah mengajar yang diperlukan agar model pembelajaran dapat dilaksanakan secara optimal.

4. Lingkungan belajar yang diperlukan agar tujuan pembelajaran dapat dicapai.

Metode kolaboratif didasarkan pada asumsi-asumsi mengenai proses belajar peserta didik sebagai berikut (Semiawan, 1992):

I. Belajar itu aktif dan konstruktif

Untuk mempelajari bahan pelajaran, peserta didik harus terlibat secara aktif dengan bahan itu. Peserta didik perlu mengintegrasikan bahan baru ini dengan pengetahuan yang telah dimiliki sebelumnya. Peserta didik membangun makna atau mencipta sesuatu yang baru yang terkait dengan bahan pelajaran.

2. Belajar itu bergantung konteks

Kegiatan pembelajaran menghadapkan peserta didik pada tugas atau masalah menantang yang terkait dengan konteks yang sudah dikenal peserta didik.
Peserta didik terlibat langsung dalam penyelesaian tugas atau pemecahan masalah itu.

3. Peserta didik itu beraneka latar belakang

Para peserta didik mempunyai perbedaan dalam banyak hal, seperti latar belakang, gaya belajar, pengalaman, dan aspirasi. Perbedaan-perbedaan itu diakui dan diterima dalam kegiatan kerjasama, dan bahkan diperlukan untuk meningkatkan mutu pencapaian hasil bersama dalam proses belajar.

4. Belajar itu bersifat sosial

Proses belajar merupakan proses interaksi sosial yang di dalamnya peserta didik membangun makna yang diterima bersama.

Menurut Piaget dan Vigotsky, strategi pembelajaran kolaboratif didukung oleh adanya tiga teori, yaitu :

I. Teori Kognitif

Teori ini berkaitan dengan terjadinya pertukaran konsep antar anggota kelompok pada pembelajaran kolaboratif sehingga dalam suatu kelompok akan terjadi proses transformasi ilmu pengetahuan pada setiap anggota.

2. Teori Konstruktivisme Sosial

Pada teori ini terlihat adanya interaksi sosial antar anggota yang akan membantu perkembangan individu dan meningkatkan sikap saling menghormati pendapat semua anggota kelompok.

3. Teori Motivasi

Teori ini teraplikasi dalam struktur pembelajaran kolaboratif karena pembelajaran tersebut akan memberikan lingkungan yang kondusif bagi peserta didik untuk belajar, menambah keberanian anggota untuk memberi pendapat dan menciptakan situasi saling memerlukan pada seluruh anggota dalam kelompok.

Piaget dengan konsepnya "active learning" berpendapat bahwa para peserta didik belajar lebih baik jika mereka berpikir secara kelompok, menurut pikiran mereka, oleh sebab itu menjelaskan sebuah pekerjaan lebih baik menampilkan di depan kelas. Piaget juga berpendapat bila suatu kelompok aktif kelompok tersebut akan melibatkan yang lain untuk berpikir bersama, sehingga dalam belajar lebih menarik (Sutikno, 2004).

Gokhale mendefinisikan bahwa "collaborative learning" mengacu pada metode pengajaran di mana peserta didik dalam satu kelompok yang bervariasi tingkat kecakapannya bekerjasama dalam kelompok kecil yang mengarah pada tujuan bersama. Pengertian kolaborasi sendiri yaitu: 
I. Keohane berpendapat bahwa kolaborasi adalah bekerja bersama dengan yang lain, kerja sama, bekerja dalam bagian satu team, dan di dalamnya bercampur didalam satu kelompok menuju keberhasilan bersama.

2. Patel berpendapat bahwa kolaborasi adalah suatu proses saling ketergantungan fungsional dalam mencoba untuk keterampilan koordinasi, to coordinate skills, tools, and rewards.

John Myers menyatakan bahwa kolaborasi berasal dari bahasa Latin, mengandung makna proses kerja bersama (Sudarman, 2008; Santyasa, 2006). Dalam sejarahnya belajar kolaboratif berakar pada pengembangan konsep dari Inggris. Basisnya adalah dinamika eksplorasi guru-guru Inggris dalam membantu peserta didik melakukan studi literatur dengan mendorong peserta didik agar mengembangkan inisiatifnya sehingga dapat belajar mandiri. Belajar berkolaborasi memiliki tradisi dalam mempelajari perkembangan belajar peserta didik dalam melakukan kajian kepustakaan melalui pendekatan kualitatif.

Dari pengertian kolaborasi yang diungkapkan oleh berbagai ahli tersebut, dapat disimpulkan bahwa pengertian belajar kolaborasi adalah suatu strategi pembelajaran di mana para peserta didik dengan variasi yang bertingkat bekerjasama dalam kelompok kecil kearah satu tujuan. Dalam kelompok ini para peserta didik saling membantu antara satu dengan yang lain. Jadi situasi belajar kolaboratif ada unsur ketergantungan yang positif untuk mencapai kesuksesan.

Bentuk kerjasama dalam belajar ini adalah metode cooperative learning. Dalam metode cooperative learning, peserta didik diarahkan untuk bisa bekerja sama, mengembangkan diri, dan bertanggung jawab secara individu (Lie, 2002). Salah satu bentuk cooperative learning adalah pengajaran oleh rekan sebaya yang biasa disebut tutor sebaya (peer tutoring). Dasar pemikiran tutor sebaya ini adalah peserta didik yang pandai dapat memberikan bantuan kepada peserta didik yang kurang pandai (Semiawan, 1992; Pietersz dan Saragih, 2010).

Teknik pembelajaran tutor sebaya yang dapat diterapkan sebagai berikut:

I. Teknik Berpikir-Berpasangan-Berempat

Teknik belajar mengajar Berpikir-BerpasanganBerempat dikembangkan oleh Frank Lyman (ThinkPair-Share) dan Spencer Kagan (Think-Pair-Square). Teknik ini melatih peserta didik untuk bekerja sendiri serta bekerja sama dengan orang lain (Lie, 2002). Teknik ini memberikan kesempatan pada peserta didik untuk dikenali dan menunjukkan partisipasi mereka kepada orang lain.

Dalam teknik ini, peserta didik dibagi dalam kelompok yang terdiri dari empat peserta didik. Saat mengerjakan tugas dari guru, peserta didik memikirkan dan mengerjakan tugas tersebut sendiri, setelah itu, peserta didik dipasangkan dengan rekan dalam kelompok dan berdiskusi dengan pasangannya. Setelah selesai berdiskusi, kedua pasangan bertemu kembali dalam kelompok berempat. Setelah kembali dalam kelompok berempat, peserta didik mempunyai kesempatan untuk membagikan hasil kerjanya kepada kelompok berempat.

\section{Teknik Two Stay Two Stray}

Teknik belajar mengajar Dua Tinggal Dua Tamu (Two Stay Two Stray) dikembangkan oleh Spencer Kagan (1992). Teknik ini memberikan kesempatan kepada kelompok untuk membagikan hasil dan informasi dengan kelompok lain (Lie, 2002).

Dalam teknik ini, peserta didik bekerja sama dalam kelompok berempat. Setelah selesai, dua orang dari masing-masing kelompok akan meninggalkan kelompoknya dan masing-masing bertamu ke dua kelompok yang lain.

Dua orang yang tinggal dalam kelompok bertugas membagikan hasil kerja dan informasi mereka ke tamu mereka. Setelah selesai, tamu mohon diri dan kembali ke kelompok mereka sendiri dan melaporkan temuan mereka dari kelompok lain.Pada akhirnya, kelompok mencocokkan dan membahas hasil-hasil kerja mereka.

Dalam pelaksanaannya, metode tutor sebaya dapat disempurnakan secara bertahap sesuai kebutuhan peserta didik dengan memanfaatkan strategi-strategi pada teknik pembelajaran Cooperative Learning, seperti Think Pair Share maupun Two Stay Two Stray.

\section{Metode Penelitian}

Metode penelitian yang digunakan dalam penulisan makalah ini adalah studi literatur. Pada studi literatur ini dibuat dan dihasilkan suatu model pembelajaran kolaboraitf dengan tutor sebaya dalam bentuk Rencana Pelaksanaan Pembelajaran (RPP) pada pokok bahasan Rangkaian Seri- 
Paralel Hambatan Listrik. Secara kualitatif penerapan RPP ini menjadikan peserta didik aktif sehingga peserta didik dapat memecahkan masalah yang diberikan oleh guru secara kooperatif dalam kelompok tutor sebaya.

\section{Hasil dan Pembahasan}

Dalam penerapan pembelajaran kolaborasi, terdapat pergeseran peran si pelajar (Sudarman, 2008; Santyasa, 2006):

I. Dari pendengar, pengamat dan pencatat menjadi pemecah masalah yang aktif, pemberi masukan dan suka diskusi.

2. Dari persiapan kelas dengan harapan yang rendah atau sedang menjadi ke persiapan kelas dengan harapan yang tinggi.

3. Dari kehadiran pribadi atau individual dengan sedikit resiko atau permasalahan menjadi kehadiran publik dengan banyak resiko dan permasalahan.

4. Dari pilihan pribadi menjadi pilihan yang sesuai dengan harapan komunitasnya.

5. Dari kompetisi antar teman sejawat menjadi kolaborasi antar teman sejawat.

6. Dari tanggung jawab dan belajar mandiri, menjadi tanggung jawab kelompok dan belajar saling ketergantungan.

7. Dahulu melihat guru dan teks sebagai sumber utama yang memiliki otoritas dan sumber pengetahuan sekarang guru dan teks bukanlah satu-satunya sumber belajar. Banyak sumber belajar lainnya yang dapat digali dari komunitas kelompoknya.

Belajar kolaboratif menuntut adanya modifikasi tujuan pembelajaran dari yang semula sekedar penyampaian informasi menjadi konstruksi pengetahuan oleh individu melalui belajar kelompok. Dalam belajar kolaboratif, tidak ada perbedaan tugas untuk masing-masing individu, melainkan tugas itu milik bersama dan diselesaikan secara bersama tanpa membedakan percakapan belajar peserta didik.

Dari uraian diatas, kita bisa mengetahui hal yang ditekankan dalam belajar kolaboratif yaitu terjadinya kerjasama, interaksi, dan pertukaran informasi antar sesama peserta didik (tutor sebaya) dalam aktivitas belajar kelompok.

Dalam proses pembelajaran pada pokok bahasan rangkaian seri-paralel hambatan listrik guru menerapkan RPP yang telah dibuat. Pada kegiatan inti guru menjelaskan konsep dan pendekatan besaran hambatan pengganti dalam rangkaian seri; menjelaskan prinsip dan penerapan besaran hambatan pengganti dalam rangkaian paralel; memberikan pre test berupa pertanyaan lisan; membentuk kelompok tutor sebaya dan membimbing siswa menyelesaikan lembar kerja; mengarahkan siswa untuk mempresentasikan hasil kerja kelompok di depan kelas; serta memotivasi siswa untuk bertanya dan menjawab pertanyaan saat forum tanya jawab.

Tutor sebaya ini melibatkan peserta didik yang ditunjuk sebagai tutor untuk membantu temannya yang mengalami kesulitan dalam belajar. Dengan demikian peserta didik tidak perlu merasa takut atau malu untuk bertanya tentang pelajaran dan soal-soal yang kurang dimengerti. Peserta didik merasa lebih nyaman untuk bertanya kepada teman karena merasa lebih dekat, lebih akrab, tidak ada rasa sungkan dan takut ditertawakan. Peserta didik yang menjadi tutor pun dapat belajar untuk bekerjasama, membantu temannya, dan mengulang kembali materi yang diajarkan.

Penerapan tutor sebaya dalam proses belajar mengajar diharapkan dapat memberikan lingkungan belajar yang penuh penguatan positif bagi peserta didik. Lingkungan belajar yang positif bagi peserta didik adalah lingkungan belajar yang penuh asosiasi positif dan menghapus ketegangan sehingga peserta didik mendapatkan kembali energinya untuk menerima pelajaran. Sedangkan lingkungan sosial yang positif bagi peserta didik adalah lingkungan yang membuat peserta didik mendapatkan pengalaman belajar secara optimal tanpa merasa terasingkan atau diremehkan.

Pada pelaksanaan tutor sebaya, proses belajar mengajar dalam kelas dilakukan secara berkelompok. Peserta didik dibagi dalam kelompok-kelompok kecil yang terdiri dari 4 peserta didik. Pengelompokkan peserta didik dibuat secara heterogen, setiap kelompok terdiri dari satu orang peserta didik pandai yang bertugas sebagai tutor, dua peserta didik yang memiliki prestasi rata-rata dan satu peserta didik yang

kurang berprestasi. Untuk itu, guru perlu membagi peserta didik dalam tiga kategori pada rentang nilai tertentu. Pada pelaksanaan di kelas, guru memberikan penjelasan umum dan poin-poin penting tentang materi pelajaran yang akan dibahas dalam hal ini adalah pokok bahasan rangkaian seri-paralel hambatan listrik. Kemudian peserta didik yang telah dipilih sebagai tutor diarahkan untuk membantu anggota kelompoknya yang mengalami kesulitan dalam belajar.

Peserta didik yang ditunjuk sebagai tutor sebelumnya telah diberikan arahan agar dengan senang hati dapat membantu anggota kelompoknya dalam menyelesaikan tugas yang diberikan, menerangkan manfaat yang dapat diperoleh oleh tutor jika membantu anggota kelompoknya, melarang tutor untuk mendominasi kelompok, atau merasa 
sombong karena paling pandai di kelompoknya. Dengan demikian kekhawatiran akan terjadi ketidakharmonisan dalam pemahaman konsep materi ajar rangkaian seri-paralel hambatan listrik dapat teratasi. Selanjutnya para anggota kelompok selain tutor disebut tutee.

Dalam penerapan metode tutor sebaya, guru berperan sebagai fasilitator. Guru mengamati dan mengawasi proses belajar peserta didik dalam kelompok dan membantu tutor yang mengalami kesulitan dalam membina kelompoknya.. Pada kasus tertentu, guru menangani peserta didik yang memerlukan bimbingan khusus.

Model pembelajaran kolaboratif dengan tutor sebaya ini memiliki kelebihan dan kelemahan. Adapun kelebihannya adalah peserta didik belajar bermusyawarah, peserta didik belajar menghargai pendapat orang lain, dapat mengembangkan cara berpikir kritis dan rasional, dapat memupuk rasa kerja sama, dan adanya persaingan yang sehat. Sedangkan kelemahannya adalah pendapat serta pertanyaan peserta didik dapat menyimpang dari pokok persoalan, membutuhkan waktu cukup banyak, adanya sifatsifat pribadi yang ingin menonjolkan diri atau sebaliknya yang lemah merasa rendah diri dan selalu tergantung pada orang lain, serta kebulatan atau kesimpulan bahan kadang sukar dicapai.

\section{Kesimpulan}

Salah satu bentuk pembelajaran kolaboratif adalah pengajaran oleh rekan sebaya yang biasa disebut tutor sebaya (peer tutoring). Dasar pemikiran tutor sebaya ini adalah peserta didik yang pandai dapat memberikan bantuan kepada peserta didik yang kurang pandai.

Pada pelaksanaan tutor sebaya, peserta didik sangat berperan penting dalam proses belajar mengajar. Metode tutor sebaya juga menciptakan kerja sama antar peserta didik sehingga terbangun lingkungan belajar yang penuh penguatan positif tanpa mengesampingkan tugas guru sebagai fasilitator dalam proses belajar mengajar di kelas.

\section{Ucapan Terimakasih}

Ucapan terima kasih disampaikan kepada Ketua STKIP Singkawang (Bapak Drs. H. Andi Mursidi, MPA., M.Si.) yang telah memberikan bantuan baik berupa moril maupun materiil serta kepada Bapak Eka Murdani, S.Si., M.PFis. selaku penulis kedua dan dosen pembimbing sehingga penulis dapat menyelesaikan makalah ini dan bisa dipublikasikan dalam Seminar Nasional Fisika 2014 di Universitas Ahmad Dahlan Yogyakarta.

\section{Kepustakaan}

Imron, Ali, Belajar dan Pembelajaran, Pustaka Jaya, 1996.

Manurung, Sondang R; Rustaman, Nuryani Y, "Hands And Minds Activity" dalam Pembelajaran Fisika Kuantum Untuk Calon Guru, Prosiding Seminar Nasional Fisika, 2010.

Semiawan, Conny, Pendidikan Keterampilan Proses, Grasindo, 1992.

Sutikno, Sobry, Menuju Pendidikan Bermutu, NTP Press, 2004.

Sudarman, Penerapan Metode Collaborative Learning untuk Meningkatkan Pemahaman Materi Mata Kuliah Metodologi Penelitian; Jurnal Pendidikan Inovatif, Vol. 3, No. 2, 2008.

Lie, Anita, Cooperatif Learning, PT Gramedia, 2002.

Pietersz, Ferry; Saragih, Horasdia, Pengaruh Penggunaan Pembelajaran Kooperatif Tipe Numbered Head Together Terhadap Pencapaian Matematika Siswa di SMP Negeri I Cisarua. Prosiding Seminar Nasional Fisika, 2010.

Santyasa, I Wayan, Pembelajaran Inovatif:Model Kolaboratif, Basis Proyek, dan Orientasi Nos, Universitas Pendidikan Ganesha, 2006. 